\title{
The Not-So-New Religious Movements: Changes in 'the Cult Scene' over the Past Forty Years
}

\author{
EILEEN BARKER \\ London School of Economics
}

\begin{abstract}
New religious movements (NRMs) tend to exhibit certain characteristics that change with the arrival of second and subsequent generations. The paper explores some of the internally motivated revisions that may be due to demographic changes or disappointed expectations, and some of the changes brought about through the economic, political, technological, legal and cultural influences from the wider society. Although there are always exceptions, unqualified boundaries tend to become more porous and negotiable as the movements accommodate to the outside world and 'denominationalise'. The paper ends with a brief description of some of the more general changes in 'the cult scene' over the past 40 years.
\end{abstract}

Keywords: cults, NRMs, new religious movements, sects, change, denominationalisation

All religions were new at their inception, although it is not always easy to say exactly when that was. Throughout history religious beliefs and practices have spread with other cultural phenomena throughout the world. Trade has been an important means of conveying cultural phenomena before, during and since the times of the early silk roads; military conquests, crusades and the slave trade have been others. More purposefully, missionaries have carried their messages to enlighten those with other beliefs to the far-flung corners of the world.

Frequently there have been sectarian schisms from more established religions: early Buddhism was a sect within the Hindu tradition; early Christianity was a sect within the Judaic tradition; early Islam was a sect in the Abrahamic tradition; early Methodism was a sect in the Christian tradition. It is possible to recognise numerous waves of NRMs at various periods. Most recently in the West, there have been the 18th century Great Awakenings of America, 19th-century revivalist movements, the prolifera- 
tion of Christian sects, and then the arrival of some esoteric and eastern innovations. The post-World War II wave of movements first became widely visible through a series of tragedies; the first of these was the 1967 murders of the pregnant Sharon Tate and others by members of the Manson Family, which was followed by the 1974 kidnapping of Patty Hearst by the Symbionese Liberation Army, and then what was arguably the most publicised tragedy of the period: the suicides and murders of over 900 members of Jim Jones' People's Temple in Guyana in 1978.

But such movements represented only the tip of an iceberg. Literally thousands of alternative religions and spiritual communities were mushrooming throughout the five continents. Inform has over 4500 religious organisations on file and there are far, far more out there. ${ }^{1}$

This paper considers the extent to which new religious movements (NRMs) might differ from older religions. Focussing mainly, though not exclusively, on the situation in the West since the Second World War, an attempt will be made to explore how variables both internal and external to the movements influence the kinds of developments that they are likely to undergo - assuming that they survive for more than a generation or two, which by no means all new religions do.

\section{What is a New Religious Movement (NRM)?}

The movements or groups with which this paper is concerned have been labelled 'cults', 'sects', new religious movements (NRMs), minority religions, alternative religions, spiritual or faith communities - and much else besides. In the sociology of religion, a commonly used distinction has been made between church, sect, denomination and cult (McGuire 2002). These were technical and non-judgemental concepts that have been useful in the past, mainly for comparisons of religions related to the Judaeo-Christian tradition. Today, however, the terms cult and sect tend, in popular parlance, to have decidedly negative overtones. To label a movement a cult can be to suggest that it is a dangerous pseudo-religion with satanic overtones which is likely to be involved in financial rackets and political intrigue, to indulge in unnatural sexual practices, to abuse its women and children, and to use irresistible and irreversible brainwashing techniques in order to exploit its recruits. Further-

1 Inform (Information Network on Religious Movements) is an educational charity founded with the support of the British government and mainstream churches in 1988 to provide information that is as accurate and up-to-date as possible about minority religions $<$ www.Inform.ac $>$. 
more, it is implied, it may well resort to violence, perform various criminal activities and, possibly, persuade its members to commit mass suicide.

Needless to say, such a 'definition' is not very helpful for a sociologist who, rather than aiming merely to label or condemn, is trying to find out about particular movements. Logically, if we want to discover whether or not a movement does in fact commit murder and/or abuse children and/or is involved in political intrigue and so on, the movement has to be defined independently of any such characteristics. We need to recognise the difference between definition and discovery; we cannot start from a definitional assumption that it does all these things. This is one reason why, since the 1970s, scholars of religion have tended to prefer the concept of new religious movement or NRM, in the hope of getting away from the popularly assumed characteristics and pejorative overtones of 'cult' and 'sect'.

\section{What is a Religion?}

But the term new religious movement also has its problems. To begin with, there is no universally agreed definition of what is 'religious'. If we confine it to belief in a God or gods, then much of Buddhism cannot be called a religion. Several groups that are termed NRMs insist they do not want to be called religious; some prefer terms such as 'spiritual community' (Findhorn; the Brahma Kumaris), or a 'spiritual way of life' (Berg's Kabbalah Centre), while the Raelian movement refers to itself as an atheistic religion.

Furthermore, whether or not a particular movement is deemed religious is not merely of academic interest. There can be substantial secular consequences depending on whether or not it is defined as a religion. In the American courts, for example, the Science of Creative Intelligence (Transcendental Meditation) has fought (albeit unsuccessfully) to be recognised as a technique rather than a religion so that it can be taught in schools and prisons, which would not be permissible according to contemporary understanding of the First Amendment (Scott 1978). On the other hand, the Church of Scientology has (successfully) fought the U.S. Inland Revenue Service to be defined as a religion and has, thereby, become eligible to receive tax privileges (Urban 2011).

Generally speaking, NRM scholars have tended to accept a relatively comprehensive understanding of religion, following the suggestion by Tillich $(1957,1-4)$ that faith, including religion, is that which offers answers to questions of ultimate concern, such as 'Is there a God?' 'What is the purpose of life?' ‘What happens at death?' It is this broad understanding of religion 
that will be used in this paper, thereby enabling the Raelians' claim that they are an atheistic religion to be perfectly reasonable.

\section{What is a Movement?}

Many of the movements are not really movements in the sense that, say, the Hizmet movement, inspired by the Turkish Islamic scholar, Fethullah Gülen (1941- ), is a movement (Ebaugh 2010); some might more appropriately be called groups, others communities, and yet others organisations, societies or networks. For present purposes the term movement will be used without any significant distinction being drawn between such categories.

\section{What is 'new'?}

Finally, it has to be asked: What is meant by 'new'. One of the first books to embrace the title New Religions (Needleman 1970) was actually concerned with some religions that had existed in the East for centuries, but were new to, and tended to display some new characteristics in, California. ${ }^{2}$ ISKCON (the International Society for Krishna Consciousness) insists that it is not new as it is been around for at least the hundreds of years that have passed since the time of Chaitanya Mahaprabhu (1486-1534), or much longer if its origins are traced back to the time of Krishna. Sociologists of religion might, however, argue that ISKCON is new in its present form, which came into existence when A. C. Bhaktivedanta Swami Prabhupada (1896-1977) came to the West in the mid-1960s.

Other religions that are not infrequently labelled cults or NRMs are what sociologists such as Bryan Wilson (1970) have referred to as 19th-century sects, examples being the Mormons; the Plymouth Brethren; the Christadelphians; the Seventh-day Adventists; the Salvation Army; Christian Science; and the Jehovah's Witnesses, founded in each of the decades from the 1820 s to the 1870 s.

\section{A Sociological Definition}

Definitions are not either true or false - they are more or less useful in helping us to understand the world. For some purposes, one definition may be more

2 Needleman's chapters included discussions about Zen, Meher Baba, Subud, Transcendental Meditation, Krishnamurti, Gurdjieff, as well as ideas such as astrology, reincarnation, American Indian religion and Western esotericism. 
useful than another, which happens to be more useful for other purposes. Different types of scholars can be concerned about different aspects of the phenomena they are studying. The historian and theologian J. Gordon Melton (2004) has commented that new religions bear more resemblance to the traditions from which they may have emerged than they do to each other. From such a perspective, a definition of a new religion as one that is in tension with society can be useful.

It is certainly true that there is an enormous variety between new religions, and it can be said that the only generalisation one can make without being shown an exception is that one cannot generalise about them. It is also incontrovertible that in order to understand the movements one needs to take into account the traditions from which they may have emerged. However, as a sociologist, I have argued (Barker 2004) that it can be useful for purposes of discovering similarities and differences between and within NRMs if one were to define the movements as those religions that have a predominantly first-generation membership.

On the other hand, while it is usually a relatively straightforward matter to distinguish between first, second and subsequent generations, the fact that some religions which now have fifth- and sixth-generation members may, at the same time, have more converts than members born into the movement can give rise to difficulties. ${ }^{3}$ For this reason we may more precisely need to define NRMs as first-generation first-generation religions.

\section{The Wide Variety of New Religions}

Among the better-known movements that became visible from around the late 1960s, were the Unification Church or, as the members were popularly known, the Moonies, with their mass weddings of thousands of couples; the Children of God (now known as The Family International), which was to become well known for its practice of 'flirty fishing' during the 1980s; ISKCON, which became readily recognisable through the devotees' chanting and dancing in the streets; the neo-sannyasin followers of Bhagwan Shree Rajneesh (later known as Osho), renowned for his fleet of 97 Rolls-Royces;

3 The Church of Jesus Christ of Latter-day Saints (the Mormons) provides an example of such a situation.

4 'Flirty fishing' or FFing was a practice introduced in the mid-1970s. Young female (and, sometimes, male) disciples ('Hookers for Jesus') would visit bars and nightclubs and, later, use escort agencies to missionise in a manner which could include sleeping with the potential convert or donor as proof of the unconditional love of Jesus (Chancellor 2000, 16). The practice gradually declined and was officially forbidden in 1987 (Melton 1997, 22-26). 
and the Church of Scientology, widely advertised for attracting celebrities such as John Travolta and Tom Cruise.

Already mentioned have been some of the movements that have led to the deaths of members and, occasionally, non-members. To their number could be added the Branch Davidians, whose compound in Waco, Texas was stormed by the FBI in 1993, resulting in 76 deaths, including 23 children; Heaven's Gate, whose members committed mass suicide in 1997 in the belief that they would be taken to another 'level of existence above human'; and the horrific murders of well over 750 members by leaders of the Movement for the Restoration of the Ten Commandments in Uganda in 2000.

Other movements that have hit the headlines at various points include the Nichiren Buddhist lay movement, Soka Gakkai International; Falun Gong, an outgrowth of the qigong movement, that has been banned in China since 1999; Anton LaVey's Church of Satan; Elijah Muhammad's Nation of Islam; Ramtha's School of Enlightenment, in which a 35,000 year old Lemurian warrior is channelled through JZ Knight; and the Twelve Tribes or Messianic Community, which has been subjected to raids from state authorities in the USA, France and Germany.

These co-exist with a multitude of lesser-known movements such as The Eternal Flame Foundation, whose members believe they have discovered the secret of eternal life - in this world; the Aetherius Society, whose members communicate with extra-terrestrial intelligences or 'Cosmic Masters'; Ravi Shankar's Art of Living; the Breatharians, who, with some tragic consequences, believe the air provides sufficient nourishment for life; the Jesus Christians, who have renounced money and advocate 'freeganism' (eating food that has been discarded); the Findhorn Community near Inverness in Scotland, that achieved a certain renown for the giant cabbages its members grew, and which now attracts visitors from around the world to take part in a variety of spiritual and self-development courses. A number of Popes have also appeared on the scene: the Apostles of Infinite Love was led by Pope Gregory XVII (aka Jean-Gaston Tremblay, 1928-2011); Clemente Domínguez y Gómez (1946-2005) was also recognised as a Pope Gregory XVII by supporters of the Palmarian Catholic Church; and Pope Michael (aka David Bawden (1959-) can be found living modestly in Kansas with his mother, Tickie.

I could go on, but the point I hope to have made is that it can be extremely difficult to generalise about NRMs; they differ in their beliefs, practices, lifestyle, leadership, finances, attitudes, and their potential for harm. There is no activity that is typical of NRMs and atypical of older religions. Each 
movement has to be looked at according to what it believes and does at a particular time and place. Furthermore, it can help us to distinguish between the movement itself (it), the leadership (him or her), and the rank-and-file members (them), a common source of confusion being when the characteristics of one are taken to refer to another.

Having spent some time trying to stress the enormous diversity and impossibility of generalising about new religious movements, I would now like (I am, after all, a sociologist of religion) to suggest that there are some characteristics of NRMs that one might at least look for when examining new NRMs.

\section{Common Characteristics of New NRMs}

First, by definition, predominantly first-generation-membership movements will consist of converts, and converts tend to be far more enthusiastic, even fanatic, than those who have been born into a religion. They are also likely to be familiar with alternative beliefs and practices and potentially vulnerable to outside influence, so it is not uncommon for novice 'true believers' to leave as quickly as they joined.

Secondly, NRMs are likely to appeal to an atypical segment of the population. In the past they have often appealed to the socially, politically, or economically oppressed. The wave of NRMs that became visible in the 1970s, however, appealed disproportionately to the young, well-educated, white middle classes. There were exceptions, such as the Rastafarians, but NRMs such as the Children of God, the Unification Church, and ISKCON attracted converts predominantly in their early twenties, and, having practically no children or older dependents, they were free to go missionising around the world with few responsibilities or encumbrances.

Thirdly, many NRMs have a founder/leader who wields a charismatic authority over far more of the followers' lives than, say, a Pope or an Archbishop of Canterbury. Being, by definition, unbound by rules or tradition, the charismatic leader is unaccountable to anyone, except, perhaps, to God (though s/he may be God), and is thus highly unpredictable and capable of dramatic changes without warning. If the movement grows, then a bureaucratic structure may be set up with the charismatic leader at the top and a top-down hierarchical authority and communication structure underneath.

A fourth characteristic often found in NRMs with charismatic leaders and fresh converts is a dichotomous worldview. Clear boundaries are drawn between, theologically, 'godly and Satanic'; morally, between 'good and bad' 
and 'right and wrong'; temporally between 'before and after' and 'then and now'; and, socially, between 'them and us'. Throughout history such sharp boundaries have helped to protect members of NRMs from equivocation and alternative worldviews. ${ }^{5}$

A fifth characteristic is that NRMs have commonly been treated with suspicion and/or antagonism by other members of society. This is not entirely surprising as they are implying, or declaring, that everyone else has got it wrong and they alone have the New Truth. This brings us to the point that one cannot understand NRMs by looking at them in isolation. Almost always, they have to function as part of a wider society - even if they live in isolated communities. Their existence is likely to be affected by, as well as to affect, relatives and friends, various types of officials, the mass media, cult-watching groups and the general public.

It is a basic assumption of the sociology of knowledge that different people perceive more or less different versions of social reality. Two people looking at what is objectively the same phenomenon can see it in significantly different ways. Sometimes we see the same thing but give it a different value. The 'real world out there' may suggest, but it does not dictate the way we construct our images of it. We tend to select what we perceive according to our interests. This means that there can be systematic differences between different versions of reality. For example, members of a religion will want to demonstrate that it is they who hold the Truth; they will incorporate those characteristics that they think will be considered 'good' and keep quiet about any skeletons that may be lurking in cupboards.

On the other hand, members of the so-called anti-cult movement, who want to control or ban the movements and warn others about the dangers of cults, will select all the 'bad' things about a movement and ignore anything that happens to be 'good' or 'normal'. The more extreme of their number can present what in some ways is a mirror image to that of the NRMs, seeing 'cults' as homogeneously bad and the rest of society as good.

A slightly different position is taken by members of the counter-cult movement, who want to show that a movement's beliefs (rather than its actions) are wrong. They will select beliefs that differ from their own and ignore those that they share with the movement. Interestingly, it is often the movements whose beliefs are most like those of a particular counter-cult group that are the focus of attention, as it is these that threaten boundaries

5 Jesus is reported as having drawn some very clear boundaries: for example, 'I am come to set a man at variance against his father, and the daughter against her mother, and the daughter-in-law against her mother-in-law.' Matthew 10:34-35 KJV. See also Luke 14:26. 
of what is, for example, 'real Christianity'. Christian counter-cultists rarely attack ISKCON, for example, as Hinduism offers no threat to the definition of Christianity.

The overriding interest of the media is to get and keep audiences. They recognise that most of us are more interested in learning about the shocking, the exotic, or the novel and much less likely to be interested in ordinary, everyday occurrences. It is not surprising then that the general public is subjected to horror stories and presented with accounts of child abuse, or Flirty Fishing ('FFing'), or pictures of the hundreds of dead followers of Jim Jones in the Guyana jungle, the release of sarin gas by members of Aum Shinrikyo in the Tokyo underground and, more recently, the bombing by Al Qaeda of the Twin Towers.

What we are less likely to recognise are pictures of the bombing of ISK$\mathrm{CON}$ in Manipur when five Americans and three French devotees were among the dead and injured. And while we may have been titillated by pictures of flirty fishers, we are less likely to have been informed about the work carried out by the Children of God/The Family International in, for example, the black townships of South Africa where they provide food for children, literacy classes, and education about the dangers of HIV and AIDS.

\section{Changes in NRMs}

Having indicated some of the general characteristics that might (or might not) be associated with new, first-generation, religious movements, the rest of this paper will discuss a sixth characteristic of NRMs: namely that they are bound to change - and this they are likely to do far more rapidly and radically than older, more established religions. Even NRMs that want to stay the same have to change in order to be able to stay the same. They will be affected by (and need to respond to) both internal and external pushes and pulls. Some changes will be specific to particular NRMs, but others will be more general.

Among the internal changes that are specific to particular movements are revisions or adjustments to their beliefs. An obvious example is to be found among NRMs that anticipate an imminent and extra-ordinary change such as the arrival of the millennium. What happens if one believes, as Harold Camping prophesied on Family Radio, that Judgement Day is 21 May 2011? Some adjustment would seem to be required if nothing obvious has happened by May 22. There are numerous strategies for dealing with such a dilemma: the members may be fired with an increasing enthusiasm 
in the way that Festinger et al (1956) describe in their now classic study, When Prophecy Fails; the date might be recalculated, as William Miller did at the time of the Great Disappointment in 1844, but there is a limit to the number of times one can plausibly do this - the Jehovah's Witnesses have not made any specific predictions since 1975 . The explanation might be that the expected happening did in fact occur, but it did so in the spirit world, or it may be said that it would have happened if only people had done what they had been told to do, or that a disaster has been prevented by the activities of the group. It may be said that the prophecy was a test of faith for the followers. Or it may simply be that that specific belief moves from the centre of the movement's general belief system to its periphery.

Other, possibly less dramatic, expectations may be tempered with the passage of time. For example, when I started studying the Unification Church in the early 1970s there was a general belief that the children born to 'Blessed couples' - that is, those who had been married by the Reverend and Mrs Moon - were born without Fallen Nature (the Unification understanding of original sin). Gradually, however, the behaviour of some of these children led the members to a somewhat different understanding. Some of the most severe tests came with revelations concerning Moon's own children. The eldest son, Hyo Jin, sometimes assumed to be the 'Crown Prince', took drugs and beat his wife while she was pregnant (Hong 1998). More recently, Moon's daughter, In Jin, who was in charge of the American church, was exposed as having had at least two extramarital affairs, and an illegitimate baby - something that seemed inconceivable to many members, given the strict and theologically critical Unification teaching that sexual relations outside wedlock were responsible for the Fall and utterly forbidden. Even more recently, allegations of Moon's own promiscuity would appear to have been established beyond reasonable doubt, ${ }^{6}$ and quite a number of Unificationists are hard-pressed to provide acceptable justifications for such behaviour, although some theological explanations have been proffered (Nevalainen 2011).

More mundane can be the challenges of communal lifestyles, many of which have been based on utopian ideals. Living together with others is rarely an easy matter and frequent adjustments have to be made if the community is to survive - which many do not. The Source Family is an example of one failure (Aquarian 2007). The Farm has survived by undergoing some radical changes (Miller 2013). A recent communication from a

6 For critical postings concerning Moon and his family, mainly by disillusioned current and former Unificationists, see How Well Do You Know Your Moon <http://howwelldoyouknowyourmoon.tumblr.com/>. 
long-term resident, Alan Bates, read '... from a Sixties commune [...] we passed through the embryo stage and are pecking at our shell, about to emerge into the light of day'. ${ }^{7}$

Another internal occurrence that an NRM might experience, especially if it has changed its original message, is the loss of some members to a schism. The Worldwide Church of God and the Church of Jesus Christ of Latter-day Saints have both experienced over 400 schisms (Barrett 2013; Bringhurst \& Hamer 2007). Nearly all the more familiar NRMs from the 1970s, such as the Unification Church, ISKCON, the Children of God and Scientology, have given rise to schisms. However, there are other movements, such as the Jesus Fellowship, that do not seem to have produced any schisms.

Although social scientists try to be as methodologically agnostic as possible, we might sometimes consider that some of the expectations held by members of NRMs are totally unrealistic. I admit to my doubts as to whether the members of the Eternal Flame Foundation really are immortal. So far as I know, they are all still alive. ${ }^{8}$ However, the Panacea Society also believed that they would live forever, and when their leader, Octavia, died the movement experienced a demoralising crisis (Shaw 2011). The Society's last member died in 2012.

Such happenings lead us to the next type of change one might anticipate in NRMs: the internal-general type. It is well-nigh inevitable that there will be shifts in the demographic composition of the movements. Charismatic leaders would seem to be as mortal as the rest of us. Almost all the wellknown NRM founders of the '60s and '70s have now died, one of the most recent being Sun Myung Moon in 2012. Only occasionally are they replaced by a new charismatic leader, and their death will frequently (though not always) result in increased accountability and predictability. Exactly what type of authority will replace a charismatic authority varies considerably according to the movement - and, indeed, the length of time since the founder died, but there is frequently a shift towards traditional and/or rational-legal authority, to employ Weber's ideal types.

Another inevitable development is that converts will mature. While young converts can insist that they are 'uniquely different' from the rest of us, in their later years they are more likely to insist that 'they are normal and just like everyone else'. More seriously, as they age, it is not uncommon for first-generation members who have devoted their lives to the movement, working for little or no pay, with no pensions and no insurance, to find

7 Email communication, 31 January 2014.

8 Since submitting this paper, one of the founders has died. 
themselves in severe financial difficulties, along with many of the other challenges that face old age (Barker 2012).

A further change that usually (but not always) accompanies the passage of time is the arrival of second and subsequent generations. Children require the diversion of important resources of time and money. Unlike difficult converts, they cannot be expelled, and the movement may have to accommodate to their demands as they grow up if it wants to keep them. Frequently the first cohort of an NRM's second generation feel they have been treated badly, one way or another, and will leave. This has happened with, for example, the Unification Church, the Children of God and ISKCON. However, the second cohort may be more likely to stay if the movement undergoes significant changes and becomes considerably less demanding. Eventually, the second generation starts to take over leadership positions, abandoning certain beliefs and practices while introducing new ones.

The potential radicalisation of such demographic changes can be graphically illustrated if we compare the age distribution of the Children of God in the 1970s with its age distribution in the 1990s. The average age was still around 23 , but the age structure was dramatically different. Indeed, it was almost a mirror image of the earlier age structure. There were almost no new converts and the movement's stress on the so-called 'Law of Love' and disapproval of the use of contraceptives meant that a large number of children had been born into the movement, ${ }^{9}$ whilst the first-generation converts had become older (Bainbridge 2002).

A different age profile is revealed if we look at the Friends of the Western Buddhist Order (or Triratna as it is now called). Although all its members did not have to be celibate, many were and few children were born into the movement, which found itself ageing to the degree that one of its members who conducted a statistical analysis pointed out that if the present trend continued the Order's average age would be around 75 in 30 years' time, with an imminent expectation that the movement, like the Shakers and the Panacea Society, would die out (Barker 2012).

As always, it is difficult to generalise, but there can be little doubt that first-generation converts have significantly different experiences from those born into a movement. Furthermore, as already indicated, the first cohort of the second-generation can have significantly different experiences from the second cohort - and third and fourth generation members will have yet more different experiences. Obviously enough, converts have converted to

9 It has been not uncommon for the women to have had a dozen or more children. 
something that is new to them, whereas life in the movement is familiar and even taken for granted for those who were born into it. Converts will have some direct knowledge of the outside and a previous identity to which they might return, unlike second-generation members, who have limited knowledge of the outside and no previous identity. The convert and the first cohort of the second generation may have a strong awareness of a sharp distinction between them and us, while the second and subsequent cohorts of second and subsequent generations are more likely to experience a more permeable boundary.

Turning to external social pressures that can bring about changes in new religions, let us first consider those that are directed at either particular NRMs or at 'cults' in general. As intimated earlier, media images of the movements have tended to be negative and sensational in character, with the mass media, then 'social media', being influential definers of NRMs. There have been relatives and friends, persuaded by media stories and/or anti-cult groups that their (adult) children were brainwashed and that if they wanted to see them (the converts) again, it was necessary to engage in the illegal practice of deprogramming - that is, kidnapping converts and holding them against their will until they manage to escape or to convince their captors that they no longer wished to remain in the movement (Patrick 1976). Hundreds of such abductions occurred during the 1970s and '80s (Bromley \& Richardson 1983), but are now rare in the West, although they continue to occur in Japan (Fautré 2012).

Further pressures had been brought to bear on the movements by the various cult-watching groups that have emerged over the period. These include members of the 'anti-cult movement', the 'counter cult movement', 'cult apologist groups', 'human rights groups' and 'research oriented groups' (Barker 2002). All these sections of society, and more, cannot be ignored for the role they can play in trying to control or bring about changes in NRMs.

In some countries (France, Belgium, Russia and China are examples), governments have introduced laws specifically targeting NRMs. Sometimes registration is mandatory and the criteria may include the number of members and length of time in the country, making it difficult for a new religion to meet the necessary requirements, which may result in certain restrictions or even banning it altogether.

Numerous legal cases have been brought both by and against NRMs, often with considerable financial consequences, and sometimes resulting in interventions such as conservatorship orders. Occasionally the outcome of a case has meant that the movement has had to change in some way. Fol- 
lowing a lengthy custody trial in Britain, the Children of God was required to denounce some of the teachings of its founder, David Berg. In 2014, the English Charity Commissioners declared that the Plymouth Brethren Christian Church, commonly known as the Exclusive Brethren, would be granted charitable status only if it agreed to certain conditions. (James 2014.)

But by no means all the external phenomena that affect NRMs are directed towards them. Wars and terrorist attacks affect all sections of society, and after 9/11 there was a very clear shift in the West, with the attention of the media and governments and, indeed, the general public being diverted from a fear of cults to fear of extreme Islamist movements.

At the same time, the cultures of societies are constantly changing, with innovations continually entering the scene and what Colin Campbell (1972) termed 'the cultic milieu'. The increasingly widespread expectation that individuals are responsible for their own life and should make choices rather than accepting conventional wisdom has played a role in encouraging the exploration of alternatives, but as society itself offers an increasing variety of choices of beliefs and lifestyles, the attraction of joining movements that offered opportunities not obviously available in the wider society has diminished as those options have become more widely available. One no longer has to join an NRM to celebrate feminism, ecological ideals or vegetarianism.

The economic situation is another variable that can affect recruitment to and life in NRMs. In the '70s, many young people were taking a gap year to travel and explore alternative experiences, while today this is a luxury that few feel able to afford.

Political changes provide further variables that can affect NRMs. China's Cultural Revolution and its aftermath provide one clear example, but another that proved to be enormously important for many Western NRMs was the collapse of the Berlin wall in 1989, when the movements had the opportunity to pour into Eastern Europe and the former Soviet Union, and where, for a short time at least, there opened up an unprecedentedly large pool of potential converts (Barker 1997).

Various technological variables can also lead to changes within NRMs. Cheap travel, migration, and the phenomenal increase in communication with the arrival of the Internet cannot be underestimated. The World Wide Web has immeasurably facilitated the dissemination of both accurate and false, and both favourable and critical information about NRMs. The movements' own websites not only advertise information about their beliefs, practices and history etc, but also offer the opportunity to buy courses, literature, DVDs, crystals, T-shirts, mugs and all manner of material and 
spiritual goods. The websites of the movements' opponents disseminate negative information. The Internet provides a means of both promoting and undermining the authority of leaders. It enables networks of current and former members to overcome leaders' obstructions to horizontal communication by facilitating communication between members and former members.

Furthermore, the Web hosts a wide range of virtual NRMs, offering a virtual community (Hutchings 2012), one example being St Pixels, originally founded in 2004 as 'Church of Fools':

We are an international community from various Christian traditions who [...] aim to create a sacred, Christ-centred space on the internet, where those of all faith and none can experience God's love as participants in a worshiping community. (Humphrey 2014.)

All these and many more variables, that are themselves constantly changing, result not only in changes within NRMs, but also in changes to the types of NRMs that emerge - or disappear. Today, one finds fewer 'world-rejecting movements' (Wallis 1984), such as the Unification Church, ISKCON or the Children of God were in the 1970s. These and other NRMs whose members devoted their lives to working for their movement and who lived in tightknit communities are now likely to have their membership living in nuclear families with outside jobs. Few people now call themselves members of the New Age as it was understood in the 1970s. Instead, there is more of a focus on 'the new spirituality', with an emphasis on 'the God within' and individual experience rather than external revelation (Barker 2008). Paganism in its various forms has become increasingly popular, with witches and Druids and worshippers of various forms of nature religions 'coming out' (Berger \& Ezzy 2007). Also increasingly visible are diverse esoteric and syncretistic movements (Hanegraaff 1998). UFO-cults still attract considerable attention (Lewis 1995) and, in addition to the arrival of virtual religions, there is a growth in movements such as 'Jediism' and 'Matrixism', the so-called 'invented' or 'hyper-real' NRMs that cannot be traced to divine intervention but are explicitly products of human imagination (Cusack 2010; Possamai 2012).

At the same time, there has been a rise in the number of Christian-based mega-churches, such as the Universal Church of the Kingdom of God, and small 'high control groups' such as the Westboro Baptist Church, which consists almost exclusively of a couple of large families who demonstrate 
at soldiers' funerals and elsewhere with banners declaring such sentiments as 'God hates fags'. There are numerous new movements within Islam, by no means all of which are extremist.

Then there has been a rise in what might be called secular NRMs - for some, Manchester United can be seen as functioning as a religion, but there are soi-disant agnostic and atheist churches popping up all over the place. The Sunday Assembly, a congregation for atheists and nonbelievers started in 2013, has overflowing crowds attending monthly services at a deconsecrated church in north London. (Knowles 2013.)

Finally, one might mention movements that few - apart, perhaps, from some of their members - would take very seriously. There is, for example, the Pastafarian membership of the Church of the Flying Spaghetti Monster, and the Universal Life Church, of which I recently became a minister on-line, enabling me, I gather, to be able to conduct marriages in parts of the USA, and which, as Dusty Hoesly (2013) has illustrated, challenges many of the characteristics of NRMs I outlined above. I was recently sent a poster for the Church of Euthanasia, which I assumed was a joke, but there are sects that persuade their members that they should become martyrs in the name of Islam. And this is no joke.

\section{‘Cult Scene' Dynamics}

So far we have looked at some of the changes that can take place within NRMs. I would like to end with a brief illustration of some dynamics involved through interactions between three types of players in the cult scene: the movements themselves, the anti-cult movement, and scholars of religion.

In the 1970s, among issues of concern for the anti-cult movement were the breaking up of families; brainwashing; finances; the physical and mental health of converts; sexual deviations; child abuse (emotional, physical and sexual); exploitation and manipulation; political intrigue; murder and/or mass suicide.

Issues for the NRMs included deprogrammings; legal cases (related to libel, brainwashing, conservatorship, child custody, peddling licences); the media generalising from a few bad apples to all NRMs (with persistent mentions of Jonestown); being labelled 'destructive cults'; apostates bearing false witness; misinterpretations; the dismissal of any good deeds as nothing but a public relations ploy - and, just, survival.

Issues for scholars of religion at a general level were (and are) the questions 'who does and believes what?' 'under what circumstances?' ‘with what 
consequences?' and 'how does this vary according to time and place?' Their interest is to produce as objective as possible a description and explanation of the phenomena they are studying. Their methods include the collection of empirical data, and comparative analyses with the use of control groups. The images that they draw of the religions they study exclude evaluative statements about the truth or falsity of their subjects' beliefs or moral judgements about their practices. They will also use concepts as tools for analysis, rather than claiming any platonic reality for them (Barker 1995).

However, around the mid-1970s, several scholars studying NRMs began to express concern about human rights violations as they observed the growing practice of illegal kidnapping and deprogramming being justified by the brainwashing metaphor, and began to ask whether they should be more proactive in trying to correct the ignorance and misinformation that they believed was being disseminated by both the movements and their opponents. This led some scholars to step outside the ivory tower of academia to appear in court cases as expert witnesses and, on occasion, to mediate between the various parties, trying to translate the perceptions of one 'side' to the other. A few went so far as to found research-oriented groups in order to promote a more social-scientific image of the movements. It was in the mid-1980s that I decided to do just that, and, with the support of the British government and mainstream churches, I set up Inform, an independent charity based at the London School of Economics. This proved to be far more controversial than I had imagined possible. Not only were both the NRMs and the anti-cultists highly suspicious of Inform, but, together with other scholars who were trying to disseminate more objective versions of 'the cult scene', we were attacked quite viciously in the media, who were fed stories by the anti-cult community, most of which were either completely untrue or just plain silly.

To exaggerate and over-simplify rather outrageously, one could describe this stage of the 'cult scene' as involving a series of processes during which the NRMs protested against society, the anti-cultists protested against the NRMs, society engaged in a moral panic, scholars protested against the anti-cultists, the anti-cultists protested against the scholars, and there developed a situation with each side exacerbating with fearsome horror stories, deprogrammings, court cases, demonstrations, and various kinds of tragic outcomes - in short, what became known in the 1970s and '80s as 'The Cult Wars'.

But nothing ever stays the same. As already intimated, NRMs tend to denominationalise, adjusting and accommodating to society (though 
not all do so, and new religions emerge). At the same time, the anti-cult movement was changing its membership. Having started as consisting almost entirely of worried relatives, they were joined by various professionals, then by former members and, more recently, second-generation adults who had left the movements in which they had been raised. There was a decline in the number of deprogrammings in the West. Some of the movements reflected this by changing their names. For example, the main British anti-cult movement was called FAIR, an acronym for Family Action Information and Rescue until, when it decided it was no longer politic to carry out deprogrammings, it was announced that FAIR stood for Family Action Information Resource. There were also fewer court cases in the USA, particularly after it had been ruled that the brainwashing hypothesis was unscientific and, thus, inadmissible evidence. And then, gradually, some of the anti-cultists responded to overtures from some scholars and started to make contact with each other - and even with a few NRMs.

One might, then, typify stage two of 'the cult scene' (as a further oversimplification and exaggeration) as a situation in which more reliable information is available; some anti-cultists, scholars and NRMs start to denominationalise and interact and cooperate - though this has sometimes led to schism; and new NRMs and anti-cultists have continued to emerge in new forms, with new beliefs and practices. In the meantime, society started to lose interest. But the cult wars still rage in some countries, and misunderstandings, misinformation and ignorance still abound.

To conclude, NRMs all start from different positions and they tend to change more rapidly and radically than older, more established religions. However, there are certain characteristics that new NRMs are likely to share just because they are new religions and, although we cannot predict what will happen to any particular movement, we can discern certain patterns and regularities in their development as new religious movements become not-so-new religious movements. 
Bibliography

Aquarian, Isis

2007 The Source: The Untold Story of Father Yo, Ya Ho Wa 13 and the Source Family. Port Townsend, WA: Process.

\section{Bainbridge, William Sims}

2002 The Endtime Family: Children of God. Albany, NY: State University of New York Press.

\section{Barker, Eileen}

1995 The Scientific Study of Religion? You Must be Joking! - Journal for the Scientific Study of Religion 34(3), 287-310.

1997 But Who's Going to Win? National and Minority Religions in PostCommunist Society. - Irena Borowik \& Grzegorz Babinski (eds), New Religious Phenomena in Central and Eastern Europe, 25-62. Kraków: Nomos.

2002 Watching for Violence: A Comparative Analysis of the Roles of Five Cult-Watching Groups. - David G. Bromley \& J. Gordon Melton (eds), Cults, Religion and Violence, 123-48. Cambridge: Cambridge University Press.

2004 What Are We Studying? A Sociological Case for Keeping the 'Nova'. - Nova Religio 8 (1), 88-102.

2008 The Church Without and the God Within: Religiosity and/or Spirituality? - Eileen Barker (ed.), The Centrality of Religion in Social Life: Essays in Honour of James A. Beckford, 187-202. Aldershot: Ashgate.

2012 Ageing in New Religions: The Varieties of Later Experiences. - Diskus: The Journal of the British Association for the Study of Religions 12. <http:// basr.ac.uk/diskus_old/diskus12/Barker.pdf/ $\geq$

\section{Barrett, David V.}

2013 The Fragmentation of a Sect: Schism in the Worldwide Church of God. New York, NY: Oxford University Press.

\section{Berger, Helen \& Douglas Ezzy}

2007 Teenage Witches: Magical Youth and the Search for the Self. New Brunswick, NJ: Rutgers University Press.

\section{Bringhurst, Newell \& John Hamer (eds)}

2007 Scattering of the Saints: Schism within Mormonism. Independence, MO: John Whitmer.

\section{Bromley, David G. \& James T. Richardson (eds)}

1983 The Brainwashing/Deprogramming Controversy: Sociological, Psychological, Legal and Historical Perspectives. New York, NY: Edwin Mellen Press. 


\section{Campbell, Colin}

1972 The Cult, the Cultic Milieu and Secularization. - A Sociological Yearbook of Religion in Britain 5, 119-36.

Chancellor, J.

2000 Life in The Family: An Oral History of the Children of God. Syracuse, NY: Syracuse University Press.

\section{Cusack, Carole}

2010 Invented Religions: Imagination, Fiction and Faith. Aldershot: Ashgate.

\section{Ebaugh, Helen Rose}

2010 The Gülen Movement: A Sociological Analysis of a Civic Movement Rooted in Moderate Islam. Dordrecht: Springer.

Fautré, Willy (ed.)

2012 Japan: Abduction $\mathcal{E}$ Deprivation of Freedom for the Purposes of Religious Deconversion. Brussels: Human Rights Without Frontiers International.

\section{Festinger, Leon \& Henry Rieken \& Stanley Schachter}

1956 When Prophecy Fails. Minneapolis, MN: University of Minnesota Press.

\section{Hanegraaff, Wouter}

1998 New Age Religion and Western Culture: Esotericism in the Mirror of Secular Thought. Albany, NY: State University of New York.

\section{Hoesly, Dusty}

2013 'We Do Not Stand Between You and Your God': The Universal Life Church as a New Religious Movement. - Paper presented at SSSR Boston and AAR Baltimore.

\section{Hong, Nansook}

1998 In the Shadow of the Moons: My Life in the Reverend Sun Myung Moon's Family. Boston \& New York: Little, Brown and Co.

\section{Hutchings, Tim}

2012 Religious Community through Online Churches. - Heidi Campbell (ed.), Digital Religion: Understanding Religious Practice in New Media Worlds, 164-72. New York, NY: Routledge.

Lewis, James R. (ed.)

1995 The Gods Have Landed: New Religions from Other Worlds. Albany, NY: State University of New York.

\section{McGuire, Meredith}

2002 Religion: The Social Context. Long Grove, IL: Waveland Press. 


\section{Melton, J. Gordon}

1997 The Children of God, 'The Family'. Torino, Italy: Elledici.

2004 Toward a Definition of 'New Religion'. - Nova Religio 8 (1), 73-87.

\section{Miller, Timothy}

2013 Intentional Communities: The Evolution of Enacted Utopianism. Eileen Barker (ed.), Revisionism and Diversification in New Religious Movements, 213-26. Farnham: Ashgate.

\section{Needleman, Jacob}

1970 The New Religions. Garden City, NY: Doubleday.

\section{Nevalainen, Kirsti}

2011 Change of Blood Lineage through Ritual Sex in the Unification Church. [n.p.]: CreateSpace Independent Publishing Platform (CPSIA)

\section{Patrick, Ted}

1976 Let Our Children Go. New York, NY: Ballantine.

Possamai, Adam (ed.)

2012 Handbook of Hyper-real Religions. Leiden: Brill.

Scott, R. D.

1978 Transcendental Misconceptions. San Diego, CA: Beta Books.

Shaw, Jane

2011 Octavia, Daughter of God: The Story of a Female Messiah and Her Followers. New Haven, CN: Yale University Press.

\section{Tillich, Paul}

1957 Dynamics of Faith. New York, NY: Harper and Row.

\section{Urban, Hugh}

2011 The Church of Scientology: A History of a New Religion. Princeton, NJ: University of Princeton Press.

\section{Wallis, Roy}

1984 The Elementary Forms of the New Religious Life. London: Routledge and Kegan Paul.

\section{Wilson, Bryan}

1970 Religious Sects: A Sociological Study. London: Weidenfeld \& Nicholson.

\section{Internet sources}

How Well Do You Know Your Moon. < http://howwelldoyouknowyourmoon. tumblr.com>, accessed 1 December 2014. 


\section{Humphrey, Rose}

2014 Welcome to St. Pixels - Church of the Internet. St. Pixels - Church of the internet. 6 September 2014. <http://www.stpixels.com/wp/>, accessed 1 December 2014.

Inform. The Information Network of Religious Movements. <http://www.inform. ac>, accessed 1 December 2014.

\section{James, Sam Burne}

2014 Charity Commission Will Accept Plymouth Brethren Application for Charitable Status. Third Sector, 9 January 2014. <http://www.thirdsector.co.uk/charity-commission-will-accept-plymouth-brethrenapplication-charitable-status/governance/article/1226627>, accessed 1 December 2014.

\section{Knowles, David}

2013 Atheist Church a Huge Success in London. New York Daily News, 6 February 2013. <http://www.nydailynews.com/news/world/atheistchurch-huge-success-london-article-1.1257274>, accessed 1 December 2014. 